THE FAMILIARITY OF STRANGERS 
This page intentionally left blank 


\section{THE FAMILIARITY OF STRANGERS}

The Sephardic Diaspora, Livorno, and

Cross-Cultural Trade in the Early Modern Period

Francesca Trivellato

Yale University Press

New Haven G London 
Published with assistance from the Kingsley Trust Association Publication Fund established by the Scroll and Key Society of Yale College and from the Frederick W.

Hilles Publication Fund of Yale University.

Copyright (c) 2009 by Yale University. All rights reserved.

This book may not be reproduced, in whole or in part, including

illustrations, in any form (beyond that copying permitted by

Sections 107 and 108 of the U.S. Copyright Law and except by

reviewers for the public press), without written permission from the publishers.

Set in Electra and Trajan types by Tseng Information Systems, Inc..

Printed in the United States of America.

Library of Congress Cataloging-in-Publication Data

Trivellato, Francesca, 1970-

The familiarity of strangers : the Sephardic diaspora, Livorno, and cross-cultural trade in the early modern period / Francesca Trivellato.

p. cm.

Includes bibliographical references and index.

ISBN 978-0-300-13683-8 (cloth : alk. paper)

1. Jews - Italy - Livorno-History - 18th century. 2. Sephardim - Italy-LivornoHistory - 18th century. 3. Jews - Italy - Livorno-Economic conditions - 18th century. 4. Sephardim - Italy-Livorno-Economic conditions - 18th century. 5. SephardimItaly-Livorno-Social conditions - 18th century. 6. Sephardim-Italy-LivornoSocial life and customs - History - 18th century. 7. Jewish merchants - Italy - Livorno-

History -18 th century. 8 . Livorno (Italy)-Commerce-History-18th century.

9. Livorno (Italy) - Ethnic relations - History - 18th century. I. Title.

$$
\begin{gathered}
\text { DS135.I85L589 } 2009 \\
305.892^{\prime} 404556-\mathrm{dc} 22 \\
2008045629
\end{gathered}
$$

A catalogue record for this book is available from the British Library.

This paper meets the requirements of ANSI/NISO Z39.48-1992 (Permanence of Paper). 